\title{
Textural and Microbiological Qualities of Vegetable Soybean (Edamame) Affected by Blanching and Storage Conditions
}

\author{
Yixiang $\mathrm{Xu}^{*}$, Edward Sismour, Steven Pao, Laban Rutto, Cory Grizzard and Shuxin Ren
}

Agricultural Research Station, Virginia State University, Petersburg, VA 23806, USA

\begin{abstract}
Vegetable soybean (edamame) is a highly perishable product. Blanching combined with cold storage is an excellent preservation method to extend edamame shelf-life. The effects of different blanching and storage conditions on textural and microbiological qualities of in-pod edamame were investigated. Blanching for 2.5 min or longer at $100^{\circ} \mathrm{C}$ water reduced peroxidase activity by over $98 \%$. The thermal denaturation temperature of edamame beans increased $30^{\circ} \mathrm{C}$ by blanching. The durations of blanching and refrigerated storage significantly influenced green color intensity and hardness of edamame beans. Green color intensity peaked as blanching time increased to $5 \mathrm{~min}$, while the hardness of the beans decreased during blanching and cold storage. Yeast, mold, and total coliform bacteria were significantly reduced by blanching, and there was no significant increase in yeast and mold counts during refrigeration for $\leq 12$ days. Addition of calcium chloride did not significantly enhance bean quality.
\end{abstract}

Keywords: Vegetable Soybean; Blanching; Calcium chloride; Cold storage; Texture; Microbiology

\section{Introduction}

Historically, tobacco has been the mainstay of many local farmbased economies in Virginia. However, production in the major tobacco producing regions of Virginia fell significantly from early 1990 to 2009 [1]. Many factors have contributed to decreased demand, including pressure on the tobacco industry from political and consumer health advocacy organizations and lower overseas production costs with increased supplies [2]. Considerable research and extension efforts have been undertaken in Virginia to assist farmers transitioning from tobacco production to alternative crops [3,4].

Vegetable soybean, also called edamame, appears to be a promising alternative for Virginia farmers. It is an edible soybean variety that generally is harvested at approximately $80 \%$ of maturity [5]. Compared to grain type soybean, edamame has some advantages as a food for human consumption, e.g. green color, soft texture, large seed size, sweet, and less beany flavor [6]. Additionally, edamame is nutritious, rich in vitamins, calcium, dietary fiber, protein, and isoflavones $[7,8]$ and offers numerous health benefits, including stronger bones and teeth, lower cholesterol levels, prevention of cardiovascular disease, and reduction in mammary and prostrate cancers [9]. Numerous and extensive efforts have been made to develop cultivars suitable for successful cultivation in Southside Virginia [10-14]. Currently, three varieties developed at Virginia State University for local growing conditions, namely Asmara, Randolph, and Owens that have been registered by the United States Department of Agriculture [15-17]. However, since edamame is well known to be a highly perishable product with a short shelf-life, the big challenge to further commercialization of this crop is to maintain postharvest shelf-life and quality [18]. Therefore, identification of methods to extend shelf-life and maintain quality is critical to successful adoption and expansion of edamame.

Cold storage, including refrigeration and freezing, is an excellent way to preserve fresh vegetables to retain valuable sensory attributes and nutritive properties [19]. However, it only slows rather than stops enzymatic and microbial degradation that causes the development of off-odors, off-flavors, changes in color and texture, and nutrient loss during long-term storage [20]. Blanching is a process in which vegetables are briefly exposed to boiling water prior to low temperature storage and serves as a necessary step to maintain vegetable quality and extend shelf life. Blanching not only inactivates enzymes and reduces the microbial load but also improves color, texture, and protein stability of the vegetables [21,22]. Peroxidase is the most popular blanching indicator enzyme to determine the adequacy of the process, since it is one of the most heat stable enzymes present in vegetables [23]. Furthermore, addition of calcium during blanching has been found to enhance texture and shelf-life of the vegetables [24].

Both the textural and microbiological qualities of processed vegetables are influenced not only by variety and maturity at harvest, but by processing and storage conditions as well. One study on frozen edamame showed that commercial frozen in-pod and shelled edamame had aerobic mesophiles at 3.4 and $3.1 \mathrm{log} \mathrm{cfu} / \mathrm{g}$, yeasts and molds at 2.3 and $2.1 \log \mathrm{cfu} / \mathrm{g}$, and some contained low levels of Escherichia coli and enterotoxigenic Bacillus spp [25]. Currently, there is no comprehensive information on blanched and cold-stored edamame. Therefore, the objective of this study was to investigate the effects of different blanching and storage conditions on textural and microbiological qualities of edamame varieties developed by Virginia State University and currently grown in Southside Virginia.

\section{Materials and Methods}

\section{Materials}

Fresh edamame (var 'Asmara'), harvested in the fall 2011 from Sussex County, Virginia was used to study. Pods were separated from the vines and hand sorted to remove debris and one-seed pods.

*Corresponding author: Yixiang Xu, Agricultural Research Station, Virginia State University, Petersburg, VA 23806, USA, Tel: +1-804-5245668; Fax: +1-804-5245186; E-mail: yixu@vsu.edu

Received June 12, 2012; Accepted July 05, 2012; Published July 10, 2012

Citation: Xu Y, Sismour E, Pao S, Rutto L, Grizzard C, et al. (2012) Textural and Microbiological Qualities of Vegetable Soybean (Edamame) Affected by Blanching and Storage Conditions. J Food Process Technol 3:165. doi:10.4172/2157. 7110.1000165

Copyright: @ $2012 \mathrm{Xu}$ Y, et al. This is an open-access article distributed under the terms of the Creative Commons Attribution License, which permits unrestricted use, distribution, and reproduction in any medium, provided the original author and source are credited. 
Approximately $1 \mathrm{~kg}$ of pods were subdivided into mesh bags, washed, and drained prior to blanching.

\section{Blanching procedure}

In-pod edamame in the mesh bags were blanched in hot water $\left(100^{\circ} \mathrm{C}\right)$ for $2.5,5$, or 10 min with $\mathrm{CaCl}_{2}$ concentrations of 1,3 and $5 \%(\mathrm{w} / \mathrm{v})$. Each bag was blanched separately, and blanched samples were rapidly cooled in ice water until the temperature at the center of the bag was $10^{\circ} \mathrm{C}$ or lower after which the samples were drained. The blanched samples were divided into seven 150 -g lots and stored in polyethylene bags. After 24 hours, the first lot was shelled for textural and microbiological analysis. The remaining lots were stored at prescribed conditions prior to being shelled for analysis.

\section{Storage conditions}

Blanched in-pod edamame was stored either in refrigerated $\left(4^{\circ} \mathrm{C}\right)$ or frozen $\left(-20^{\circ} \mathrm{C}\right)$ conditions. Qualities of the edamame stored at $4^{\circ} \mathrm{C}$ were evaluated at days $1,5,8$ and 12 , while the evaluations were carried out at one week, one month, and three months for the samples stored at $-20^{\circ} \mathrm{C}$. Raw and blanched in-pod edamame stored at $22^{\circ} \mathrm{C}$ and refrigerated $\left(4^{\circ} \mathrm{C}\right)$ were used as controls.

\section{Peroxidase (POD) assay}

Crude enzyme extraction was carried out by homogenizing $2 \mathrm{~g}$ of shelled beans with $10 \mathrm{ml}$ of chilled distilled water at $4^{\circ} \mathrm{C}$ in a laboratory blender (Masticator, IUL Instruments, Barcelona, Spain) for $2 \mathrm{~min}$. The slurry was filtered through three layers of cheesecloth and centrifuged at $20,000 \mathrm{xg}$ for $30 \mathrm{~min}$ at $4^{\circ} \mathrm{C}$. The supernatant was used as the crude enzyme extract. POD activity was measured using a spectrophotometric method as described by [26] with some modifications. POD substrate solution was prepared freshly by mixing $0.1 \mathrm{~mL}$ guayacol, $0.1 \mathrm{~mL}$ hydrogen peroxide (30\%), and $99.8 \mathrm{~mL}$ potassium phosphate buffer (0.1 M; pH 6.5), and homogenizing for $30 \mathrm{~s}$, followed by transferring $1 \mathrm{~mL}$ into a $1-\mathrm{cm}$ cuvette. The reaction was started by adding $0.2 \mathrm{ml}$ of crude enzyme extract. POD unit activity was defined as a 0.001 increase in absorbance at $420 \mathrm{~nm}$ per minute per gram of fresh sample.

\section{Thermal denaturation temperature}

Thermal stability of raw and blanched beans was measured using a Differential Scanning Calorimeter (DSC) (TA Instruments, New Castle, DE). Shelled beans were freeze-dried then ground. Dried samples (9$10 \mathrm{mg}$ ) were sealed in aluminum pans before heating in the DSC. The heating range and rate were $40^{\circ} \mathrm{C}$ to $200^{\circ} \mathrm{C}$ and $10^{\circ} \mathrm{C} / \mathrm{min}$, respectively. Indium and zinc were used for calibration and an empty pan was used as a reference. Thermal denaturation temperature is defined as the maximum of the melting peak.

\section{Color measurement}

Change in color over time was measured with a Minolta CR400/410 chromameter (Minolta Camera Co., Ltd, Osaka, Japan) to determine ' $L$ ', ' $a$ ' and ' $b$ ' values. ' $L$ ' indicates lightness using a scale from black (0) to white (100), while 'a' denotes the red $(+a)$ to green $(-a)$ color axis and 'b' denotes the yellow $(+b)$ to blue (-b) color axis. The instrument was calibrated on a white card with values $L=93.6$, a $=0.6$ and $b=2.3$. Seed color values represent average of three readings. Intensity of green color was calculated $a s-a / b$.

\section{Texture analyzer}

The hardness of the edamame seeds was quantified using a TA.XT 2 Texture Analyzer (Robbinsville, NJ) with a 50-kg load cell and fitted with a TA-65 13-point needle probe. An acrylic cylinder contained the seeds. For each analysis, a sample of edamame beans $(60 \mathrm{~g})$ was loaded into the cylinder and agitated to promote compaction. The probe was set initially to a standard height of $40 \mathrm{~mm}$ above the bottom of the cylinder. The probe penetrated the sample at a rate of $1 \mathrm{~mm}$ per second for total distance of $38 \mathrm{~mm}$ ( $95 \%$ of initial height). Each sample was measured three times, and the cylinder was shaken between each run to redistribute the seeds. The maximum peak height of the forcedeformation curve was used as the hardness criterion.

\section{Microbiological quality}

Standard plate count method was used to evaluate the population of microorganism in the edamame samples. Treated or non-treated control samples were macerated in a lab blender in sterile blender bags. Appropriate dilutions of the macerated were surface plated onto standard plate count agar for total aerophilic mesophiles and onto acidified potato dextrose agar for yeasts and molds. Colonies were enumerated after incubation for $48 \mathrm{~h}$ at $36^{\circ} \mathrm{C}$ and 5 days at $22^{\circ} \mathrm{C}$, respectively. An additional set of standard plate count agar plates were overlaid with violet red bile agar followed by $24-48 \mathrm{~h}$ incubation at $36^{\circ} \mathrm{C}$ for total coliform bacteria counts.

\section{Statistical analyses}

Each treatment was evaluated using triplicate samples. Statistical analyses were conducted using SAS (version 9.2, SAS Institute Inc., Cary, NC). Effects of blanching on POD activity was analyzed using SAS PROC mixed procedure. Effects of blanching and refrigerated storage on color and texture were analyzed using SAS PROC rsreg procedure for multiple regression analysis. A second-order polynomial regression model was employed to calculate the predicted response variables.

$$
\mathrm{Y}=\mathrm{b}_{0}+\sum \mathrm{b}_{\mathrm{n}} \mathrm{X}_{\mathrm{n}}+\sum \mathrm{b}_{\mathrm{nn}} \mathrm{X}_{\mathrm{n}}^{2}+\sum \mathrm{b}_{\mathrm{nm}} \mathrm{X}_{\mathrm{n}} \mathrm{X}_{\mathrm{m}}+\varepsilon
$$

where $\mathrm{Y}$ is the response variable, $\mathrm{b}_{0}$ is the intercept coefficient, $\mathrm{b}_{\mathrm{n}}, \mathrm{b}_{\mathrm{n}}$, $\mathrm{b}_{\mathrm{nm}}$ are the linear, quadratic and cross product regression coefficients, respectively, $\mathrm{X}$ is the independent variable, and $\varepsilon$ is the experimental error $(\mu=0, \sigma=1)$. The coefficient of multiple determinations, $R^{2}$, was used to evaluate model fit. ANOVA with Duncan's Multiple Range test was used for other evaluations. Probability $(P)<0.05$ indicates significance.

\section{Results and Discussion}

\section{Effect of blanching on POD activity and thermal denaturation}

POD serves as a blanching indicator in the process of blanching vegetables. The residual activities of POD in edamame as a function of blanching time at various calcium chloride concentrations are shown in Figure 1. POD activity in raw edamame averaged $2.22 \mathrm{abs} \cdot(\mathrm{min} \cdot \mathrm{g})^{-1}$. Enzyme activity was dramatically reduced by blanching, with $98 \%$ loss in activity after just $2.5 \mathrm{~min}$. This is consistent with a $90 \%$ reduction of POD activity that occurred after blanching vegetable soybeans for $1.14 \mathrm{~min}$ at $100^{\circ} \mathrm{C}$ water [26]. Blanching time and calcium chloride concentration had significant effects on enzyme inactivation. Longer blanching times and higher calcium chloride concentrations resulted in progressively greater enzyme inactivation.

The effect of blanching on thermal denaturation temperature of edamame was determined by DSC, and typical DSC curves for dried raw and blanched edmames are presented in Figure 2. Thermal denaturation temperature of freeze-dried edamame significantly increased from $142^{\circ} \mathrm{C}$ for raw samples to $174^{\circ} \mathrm{C}$ for the blanched 
counterpart. This is in agreement with another study in which they found thermal denaturation temperature of the several green vegetables increased significantly [27]. The results indicated that blanching has the favorable effect for the vegetable to resist heat denaturation. The thermal denaturation temperature is inversely related to the moisture content of the sample [28]. Higher thermal denaturation temperature in our samples was attributed to the lower moisture content. Extending blanching time or adding calcium chloride was found not to significantly increase thermal denaturation temperature of the beans.

\section{Effect of blanching and refrigerated storage on color and hardness}

Intensity of green color and hardness are two important indices for textural quality of processed vegetables. The effects of the independent variables (blanching time, calcium chloride concentration, and storage time) as linear, quadratic and interaction terms on response variables (intensity of green color and hardness) of edamame were determined for adequacy of the model by analysis of variance (Table 1). Generally, it was found that for each response variable, the second-order model was adequate with a high $\mathrm{R}^{2}$. Linear, quadratic and total models were statistically significant $(P<0.05)$ with no significant $(P>0.05)$ interaction terms.

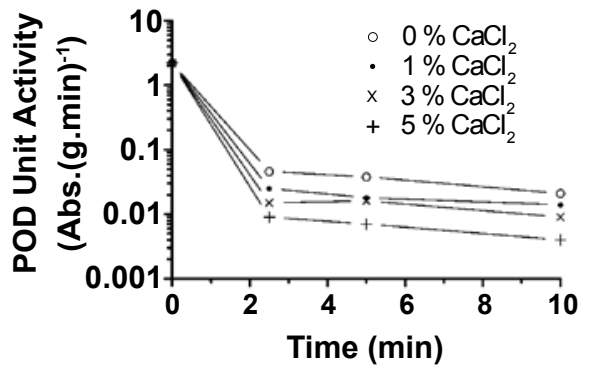

Figure 1: Xu et al.,

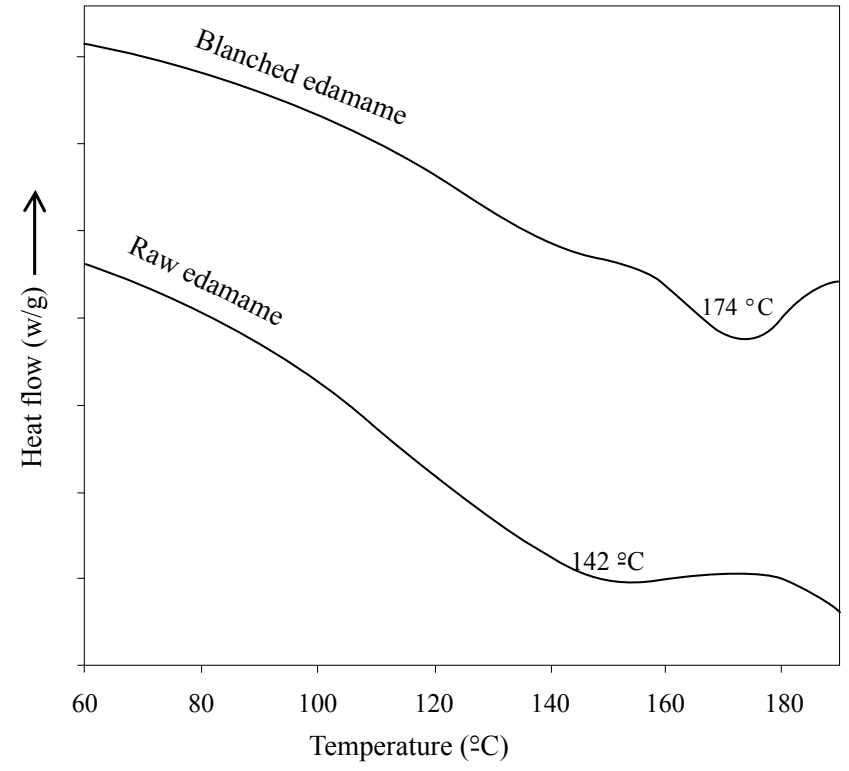

Figure 2: Xu et al.

\section{Intensity of green color}

Statistical analysis showed significant linear and quadratic terms for green color intensity (Table 1). A high $\mathrm{R}^{2}(0.899)$ indicated that the fitted second-order polynomial model accounted for $89.9 \%$ of the variance in the experimental data. The effects of blanching time and refrigerated storage time were significant, whereas no significant effect was found for calcium chloride (Table 2). The regression model that describes this relationship is

$$
\mathrm{Y}_{\mathrm{c}}=0.537+0.016 \mathrm{X}_{1}-0.014 \mathrm{X}_{2}-0.0016 \mathrm{X}_{1}^{2}+0.000435 \mathrm{X}_{2}^{2}
$$

Where $\mathrm{Y}_{c}$ is intensity of green color, and $\mathrm{X}_{1}$ and $\mathrm{X}_{2}$ are blanching time and storage time, respectively.

Based on the predictive models, the linear and quadratic effects of blanching time and storage time were involved. The fitted responses for the intensity of green color as a function of blanching time and storage period were plotted (Figure 3). Green color intensity increased nonlinearly as blanching times increased to $5 \mathrm{~min}$ and subsequently decreased with further blanching. Our findings are not consistent with the results obtained by Monzzoni et al. [29] who found that the intensity of green color decreased for cooked ( $5 \mathrm{~min}$ ) compared to raw edamame. This difference may be attributable to the enhancement of green color by addition of calcium chloride into the blanching water or difference of the varieties studied [30]. In addition, the decrease in green color intensity with blanching over an extended period of time could be explained by the conversion of chlorophylls to pheophytins [31]. Increasing storage time contributed to the decrease in green color intensity in all blanched samples due to degradation of chlorophylls.

\section{Hardness}

Analysis of variance indicated that the linear, quadratic and total models were significant $(P<0.05)$ for hardness. Based on t-test, only the regression coefficients significant at the $95 \%$ level were selected for developing the models (Table 2). The regression model that describes this relationship is

$$
\mathrm{Y}_{\mathrm{h}}=7439-592 \mathrm{X}_{1}-270 \mathrm{X}_{2}+38.3 \mathrm{X}_{1}^{2}+13.7 \mathrm{X}_{2}^{2}
$$

Where $Y_{h}$ is the hardness of beans, and $X_{1}$ and $X_{2}$ are blanching time and storage time, respectively.

From the above regression model, it was observed that the hardness of the beans was affected by the linear and quadratic terms of blanching time and storage time. The regression model for hardness explained $77.6 \%$ of the total variation (Table 1). The relationships between bean hardness and blanching time or storage time are shown in Figure 4. Blanching resulted in a significant reduction of bean hardness from $7183 g_{f}$ for raw samples to $5942 g_{f}$ for samples blanched for $2.5 \mathrm{~min}$. Hardness continued to decrease with increased blanching time to $5180 g_{f}$ at $10 \mathrm{~min}$. Starch and pectin are responsible for hardness of edamame [32], and the decrease in hardness of the edamame beans during blanching was attributed to starch gelatinization and pectin solubilization [5]. On the other hand, as storage times increased, the hardness of the beans first decreased, reaching the lowest point at day 8 , followed by a slight increase as storage time was increased to 12 days. This could be explained by the retrogradation of bean starch or water loss during refrigeration.

\section{Effect of blanching and refrigerated storage on microbiological quality}

Prior to blanching, raw edamame from the field had total aerobic mesophile, yeast and mold, and coliform counts at 6.20, 2.76, and 4.50 
Citation: Xụ Y, Sismour E, Pao S, Rutto L, Grizzard C, et al. (2012) Textural and Microbiological Qualities of Vegetable Soybean (Edamame) Affected by Blanching and Storage Conditions. J Food Process Technol 3:165. doi:10.4172/2157-7110.1000165

\begin{tabular}{|c|c|c|c|c|}
\hline \multirow[t]{2}{*}{ Source } & \multicolumn{2}{|c|}{ Intensity of green color (-a/b) } & \multicolumn{2}{|c|}{ Hardness (Force, $g_{f}$ ) } \\
\hline & Sum of squares ${ }^{1}$ & $\operatorname{Pr}>\mathrm{F}$ & Sum of squares ${ }^{1}$ & $\operatorname{Pr}>\mathrm{F}$ \\
\hline Linear & $0.104<0.0001$ & & $8.914 \times 10^{6}$ & $<0.0001$ \\
\hline Quadratic & $0.017<0.0001$ & & $8.637 \times 10^{6}$ & $<0.0001$ \\
\hline Crossproduct & 0.00190 .145 & & $8.471 \times 10^{5}$ & 0.099 \\
\hline Total model & $0.123<0.0001$ & & $1.840 \times 10^{7}$ & $<0.0001$ \\
\hline $\mathrm{R}^{2}$ & 0.899 & & 0.776 & \\
\hline
\end{tabular}

Significance level was defined as $P<0.05$; and ${ }^{1}$ Refers to Type I error

Table 1: Analysis of variance for intensity of green color and hardness as linear, quadratic term and interaction on response variables.

\begin{tabular}{|c|c|c|c|c|c|}
\hline \multirow[t]{2}{*}{$\begin{array}{l}\text { Independent } \\
\text { variable }\end{array}$} & \multicolumn{2}{|c|}{$\begin{array}{l}\text { Intensity of green } \\
\text { color }\end{array}$} & \multicolumn{3}{|l|}{ Force $\left(g_{f}\right)$} \\
\hline & Coefficients & $\mathrm{Pr}>\mathrm{t}$ & Coefficients & $\operatorname{Pr}>t$ & \\
\hline$b_{0}$ & $5.37 \times 10^{-1}$ & $<0.0001$ & $7.44 \times 10^{3}$ & $<0.0001$ & \\
\hline $\mathrm{b}_{1}$ & $1.59 \times 10^{-2}$ & 0.0001 & $-5.92 \times 10^{2}$ & $<0.0001$ & \\
\hline$b_{2}$ & $1.85 \times 10^{-2}$ & 0.0579 & $-2.21 \times 10^{2}$ & 0.2420 & \\
\hline$b_{3}^{2}$ & $-1.44 \times 10^{-2}$ & $<0.0001$ & $-2.70 \times 10^{2}$ & $<0.0001$ & \\
\hline$b_{1}^{3}$ & $-1.61 \times 10^{-3}$ & $<0.0001$ & 38.3 & $<0.0001$ & \\
\hline$b_{2}^{2}$ & $-1.13 \times 10^{-3}$ & 0.6689 & -21.9 & 0.6724 & \\
\hline$b_{3}^{2}$ & $4.35 \times 10^{-4}$ & 0.0178 & 13.7 & 0.0003 & \\
\hline$b_{12}^{3}$ & $-1.31 \times 10^{-3}$ & 0.0644 & 12.4 & 0.36376 .24 & 0.0923 \\
\hline$b_{13}^{12}$ & $-6.43 \times 10^{-5}$ & 0.7286 & 15.7 & 0.1397 & \\
\hline$b_{23}^{13}$ & $-7.58 \times 10^{-4}$ & 0.1617 & & & \\
\hline
\end{tabular}

Significance level was defined as $P<0.05$; the values in bold indicate the significance

Table 2: Regression coefficients of second-order polynomials for response variables (intensity of green color and hardness)

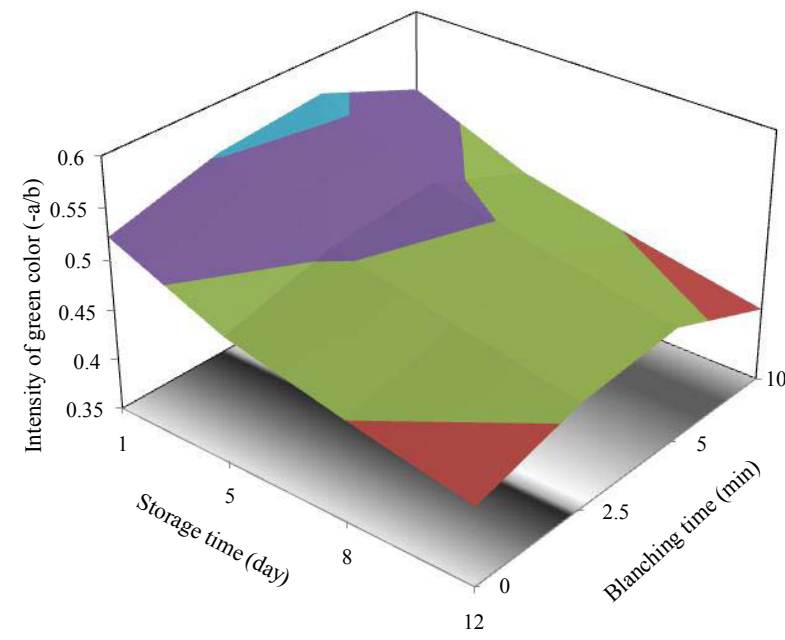

Figure 3: Xu et al.

$\log \mathrm{CFU} / \mathrm{g}$ levels. The counts of these naturally existing microorganisms did not change significantly $(\mathrm{P}>0.05)$ during subsequent storage of the untreated edamame at either 4 or $22^{\circ} \mathrm{C}$. Blanching significantly reduced total yeast, mold, and coliform bacteria counts to either below or near the detection level (1 log CFU/g). Some presumably thermaltolerant bacteria, however, survived the blanching treatments. Multiple comparisons show that treatment time, but not calcium concentration, was a significant factor $(P<0.001)$ affecting microbial survival. The average total aerobic mesophile count was reduced $3.8,4.0$, and $4.6 \log$ CFU cycles by $2.5,5$, and 10 min of blanching, respectively.

Data in Table 3 show that counts of aerobic mesophiles on processed edamame increased during refrigeration and were higher for samples blanched for $10 \mathrm{~min}$ (2.70 log cycles of growth) compared to those blanched for either $2.5 \mathrm{~min}$ (1.81 log cycles) or $5 \mathrm{~min}$ (1.70 log cycles). Statistically significant growth of the microbes was observed at day 8 in edamame blanched $10 \mathrm{~min}$ in 1 and $2 \%$ calcium chloride and day 12 in edamame blanched $10 \mathrm{~min}$ at all calcium levels, $5 \mathrm{~min}$ in $0 \%$ or $2 \%$ calcium, or $2.5 \mathrm{~min}$ in $1 \%$ or $3 \%$ calcium. None of the blanched samples had microbial counts $\geq 5 \log \mathrm{CFU} / \mathrm{g}$ at day 8 , yet spoilage of samples blanched for 10 min was observed after 12 days of refrigeration. In general, microbial growth during storage was not significantly influenced by the presence of calcium.

Growth of coliform bacteria in blanched edamame stored at $4^{\circ} \mathrm{C}$ is presented in Table 4. Blanching reduced yeast and mold and total coliform counts to $\leq 1.15$ and $\leq 1.00 \log$ CFU/g in all analyzed samples, respectively. The yeast and mold counts did not significantly increase during refrigeration for $\leq 12$ days. However, total coliform counts on edamame blanched for $2.5,5$, and 10 min increased 2.02, 1.35, and 2.00 $\log$ cycles, respectively, over this time. Statistically significant increase in the total coliform count was observed at Day 8 in samples blanched for 5 min with $3 \%$ calcium salt and Day 12 in samples blanched for $2.5,5$, and 10 min with $3 \%, 1-2 \%$, and $\geq 1 \%$ calcium salt, respectively. In general, coliform growth during storage was independent of the presence of calcium during blanching. Current Food Code requires

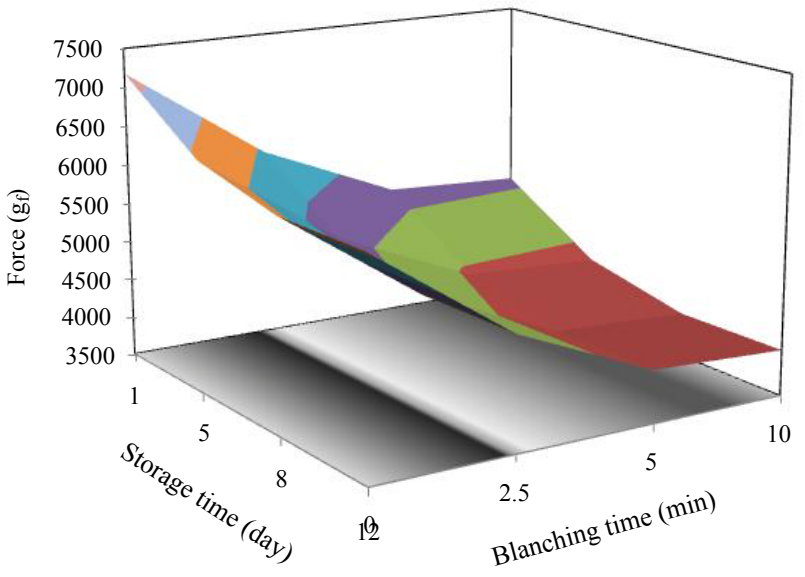

Figure 4: Xu et al.,

\begin{tabular}{|c|l|l|l|l|l|}
\hline \multicolumn{3}{|c|}{ Blanching } & \multicolumn{4}{|c|}{ Aerobic Mesophiles (Log CFU/g ) } \\
\hline Time (min) & Calcium \% & Day 1 & Day 5 & Day 8 & Day 12 \\
\hline \multirow{4}{*}{2.5} & 0 & $2.13 \pm 0.07 \mathrm{a}^{*}$ & $1.95 \pm 0.47 \mathrm{a}$ & $2.86 \pm 0.48 \mathrm{a}$ & $3.06 \pm 0.41 \mathrm{a}$ \\
\hline & 1 & $1.90 \pm 0.60 \mathrm{a}$ & $2.25 \pm 0.26 \mathrm{a}$ & $3.03 \pm 0.64 \mathrm{a}$ & $5.68 \pm 1.11 \mathrm{~b}$ \\
\hline & 2 & $2.53 \pm 0.26 \mathrm{a}$ & $2.20 \pm 0.19 \mathrm{a}$ & $3.05 \pm 0.43 \mathrm{a}$ & $3.32 \pm 0.89 \mathrm{a}$ \\
\hline \multirow{5}{*}{5} & 3 & $3.07 \pm 0.39 \mathrm{a}$ & $1.86 \pm 0.20 \mathrm{~b}$ & $2.52 \pm 0.36 \mathrm{ab}$ & $4.81 \pm 0.19 \mathrm{c}$ \\
\hline & 0 & $2.06 \pm 0.68 \mathrm{a}$ & $1.90 \pm 0.63 \mathrm{a}$ & $2.40 \pm 0.43 \mathrm{ab}$ & $4.15 \pm 0.51 \mathrm{~b}$ \\
\hline & 1 & $2.43 \pm 0.38 \mathrm{a}$ & $1.87 \pm 0.32 \mathrm{a}$ & $2.48 \pm 0.62 \mathrm{a}$ & $3.57 \pm 0.88 \mathrm{a}$ \\
\hline \multirow{5}{*}{10} & 2 & $2.11 \pm 0.05 \mathrm{a}$ & $1.64 \pm 0.62 \mathrm{a}$ & $2.87 \pm 1.30 \mathrm{ab}$ & $4.28 \pm 2.32 \mathrm{~b}$ \\
\hline & 3 & $2.18 \pm 0.21 \mathrm{a}$ & $2.32 \pm 0.28 \mathrm{a}$ & $3.05 \pm 0.24 \mathrm{a}$ & $3.57 \pm 0.82 \mathrm{a}$ \\
\hline & 0 & $1.72 \pm 0.10 \mathrm{a}$ & $1.36 \pm 0.10 \mathrm{a}$ & $2.54 \pm 0.01 \mathrm{ab}$ & $3.65 \pm 0.92 \mathrm{~b}$ \\
\hline & 1 & $1.80 \pm 0.34 \mathrm{a}$ & $1.80 \pm 0.70 \mathrm{a}$ & $3.59 \pm 0.77 \mathrm{~b}$ & $4.87 \pm 0.35 \mathrm{~b}$ \\
\hline & 2 & $1.56 \pm 0.49 \mathrm{a}$ & $1.70 \pm 0.39 \mathrm{a}$ & $3.31 \pm 1.47 \mathrm{~b}$ & $4.76 \pm 0.76 \mathrm{~b}$ \\
\hline & 3 & $1.30 \pm 0.52 \mathrm{a}$ & $1.20 \pm 0.17 \mathrm{a}$ & $2.08 \pm 0.07 \mathrm{a}$ & $3.88 \pm 1.51 \mathrm{~b}$ \\
\hline
\end{tabular}

Data represent the means of log values \pm S.E. Means in same rows followed by an identical letter were not statistically different $(P>0.05)$

Table 3: Growth of aerobic mesophiles in blanched edamame stored at $4^{\circ} \mathrm{C}$. 
Citation: Xụ Y, Sismour E, Pao S, Rutto L, Grizzard C, et al. (2012) Textural and Microbiological Qualities of Vegetable Soybean (Edamame) Affected by Blanching and Storage Conditions. J Food Process Technol 3:165. doi:10.4172/2157-7110.1000165

Page 5 of 6

\begin{tabular}{|c|c|c|c|c|c|}
\hline \multicolumn{2}{|c|}{ Blanching } & \multicolumn{4}{|c|}{ Total Coliform Counts (Log CFU/g ) } \\
\hline Time (min) & Calcium \% & Day 1 & Day 5 & Day 8 & Day 12 \\
\hline \multirow{4}{*}{2.5} & 0 & $1.00 \pm 0.00 a$ & $1.00 \pm 0.00 a$ & $1.30 \pm 0.30 a$ & $2.27 \pm 0.64 a$ \\
\hline & 1 & $1.00 \pm 0.00 a$ & $1.43 \pm 0.51 \mathrm{a}$ & $1.92 \pm 0.84 a$ & $2.42 \pm 2.47 a$ \\
\hline & 2 & $1.00 \pm 0.00 \mathrm{a}$ & $1.00 \pm 0.00 a$ & $1.74 \pm 0.72 a$ & $2.68 \pm 2.38 a$ \\
\hline & 3 & $1.00 \pm 0.00 a$ & $1.36 \pm 0.62 a$ & $2.11 \pm 0.90 \mathrm{ab}$ & $4.71 \pm 0.65 b$ \\
\hline \multirow{4}{*}{5} & 0 & $1.00 \pm 0.00 \mathrm{a}$ & $1.23 \pm 0.40 a$ & $1.75 \pm 0.74 a$ & $2.84 \pm 1.08 a$ \\
\hline & 1 & $1.00 \pm 0.00 \mathrm{a}$ & $1.00 \pm 0.00 a$ & $1.90 \pm 0.85 \mathrm{ab}$ & $4.23 \pm 0.26 b$ \\
\hline & 2 & $1.00 \pm 0.00 \mathrm{a}$ & $1.32 \pm 0.55 a$ & $1.49 \pm 0.50 \mathrm{ab}$ & $3.27 \pm 0.31 b$ \\
\hline & 3 & $1.00 \pm 0.00 \mathrm{a}$ & $1.00 \pm 0.00 a$ & $2.44 \pm 0.14 b$ & $1.55 \pm 0.95 \mathrm{ab}$ \\
\hline \multirow{4}{*}{10} & 0 & $1.00 \pm 0.00 \mathrm{a}$ & $1.00 \pm 0.00 a$ & $2.24 \pm 0.05 a$ & $1.00 \pm 0.00 \mathrm{a}$ \\
\hline & 1 & $1.00 \pm 0.00 a$ & $1.44 \pm 0.76 a b$ & $2.38 \pm 0.29 a b$ & $2.94 \pm 2.07 b$ \\
\hline & 2 & $1.00 \pm 0.00 a$ & $1.37 \pm 0.64 a$ & $1.57 \pm 0.75 a$ & $4.18 \pm 0.74 b$ \\
\hline & 3 & $1.00 \pm 0.00 \mathrm{a}$ & $1.00 \pm 0.00 a$ & $1.30 \pm 0.52 a$ & $2.53 \pm 1.64 b$ \\
\hline
\end{tabular}

Data represent the means of log values \pm S.E. Means in same rows followed by an identical letter were not statistically different $(P>0.05)$

Table 4: Growth of coliform bacteria in blanched edamame stored at $4^{\circ} \mathrm{C}$.

\begin{tabular}{|c|c|c|c|c|}
\hline \multicolumn{2}{|c|}{ Blanching } & \multicolumn{3}{|l|}{ Storage time } \\
\hline Time (min) & Calcium \% & One week & One month & Three months \\
\hline & & \multicolumn{3}{|l|}{ Intensity of green color (-a/b) } \\
\hline 2.5 & 0 & $0.56 \pm 0.02 a$ & $0.55 \pm 0.01 a$ & $0.56 \pm 0.01 a$ \\
\hline \multirow[t]{2}{*}{10} & 0 & $0.47 \pm 0.02 a$ & $0.47 \pm 0.01 a$ & $0.44 \pm 0.06 a$ \\
\hline & & \multicolumn{3}{|l|}{ Force $\left(g_{f}\right)$} \\
\hline 2.5 & 0 & $5320 \pm 22.3 a$ & $4228 \pm 291 b$ & $3563 \pm 190 c$ \\
\hline 10 & 0 & $4583 \pm 628 a$ & $3697 \pm 0.40 b$ & $2803 \pm 197 c$ \\
\hline
\end{tabular}

Data represent the mean \pm S.E. Means in same rows followed by an identical letter were not statistically different $(P>0.05)$

Table 5: Intensity of green color and hardness of selected blanched edamame stored under frozen for different time intervals.

that refrigerated food items prepared in advanced be discarded after 7 days. Our data agrees that blanched edamame, regardless of calcium treatments, can be refrigerated for 7 days without encountering excessive microbial proliferation. Adequate refrigeration time and temperature should be monitored for protecting the microbiological quality of blanched edamame.

\section{Effect of frozen storage on textural quality of blanched samples}

The effects of frozen storage on color and hardness of selected blanched samples are presented in Table 5. During frozen storage from one week to three months, green color of the beans was retained, while hardness significantly decreased for all the samples. Hardness decreased by $67 \%$ for the samples blanched for $2.5 \mathrm{~min}$ and $61 \%$ for those blanched for $10 \mathrm{~min}$. Textural changes in frozen vegetables are affected by blanching, freezing and storage conditions, with blanching influence related to inactivation of pectinesterase [33]

\section{Conclusion}

Blanching significantly decreased peroxidase activity, and total yeast, mold, and coliform bacteria counts, but increased the thermal denaturation temperature of edamame beans. Green color and hardness of the beans were significantly affected by blanching time and refrigerated storage time, with the linear and quadratic effects of these two independent factors involved. Incorporation of calcium chloride in the blanch water did not significantly influence textural qualities of the beans or the growth of aerobic mesophiles during refrigerated storage. This could be explained by that fact that calcium chloride did not effectively penetrate the pod to function as a quality-enhancing agent. Green color did not change significantly during frozen storage, while hardness significantly decreased for all the samples.

\section{Acknowledgement}

The authors thank Drs. Chyer Kim, Sarah Weeda, Ms. Kaitlin Coffey, Ms. Brittany Wood, Mr. Michael Brandt, and Mr. Waverly Massenburg for technical supports. Funding was provided through the Virginia Agricultural Council and the USDA Evans-Allen program, and the research was conducted at Virginia State University Agricultural Research Station.

\section{References}

1. http://www.nass.usda.gov/

2. Barnard C (2006) Farm real estate values, In Wiebe K, Gollehon N, Agricultura Resources and Environmental Indicators, Economic Information Bulletin No. EIB-16, USDA/ERS, USA.

3. Newton SH (1995) Virginia aquaculture plan: executive summary and recommendations/ prepared by the Virginia Department of Agriculture and Consumer Services, USA.

4. Bhardwaj HL, Hankins A, Mebrahtu T, Mullins J, Rangappa M, et al. (1996) Alternative crops research in Virginia, In: J. Janick, Progress in new crops. ASHS Press, Alexandria,Virginia, 87-96.

5. Song JY, Gil-Hwan An, Kim CH (2003) Color, texture, nutrient contents, and sensory values of vegetable soybean [Glycine $\max (\mathrm{L}$.) Merrill] as affected by blanching. Food Chemistry 83: 69-74.

6. Saldivar X, Wang YJ, Chen P, Mauromoustakos A (2010) Effects of blanching and storage conditions on soluble sugar contents in vegetable soybean. LWTFood Science and Technology 43: 1368-1372.

7. Johnson D (2000) Edamame. Engineering and Technology for a Sustainable World 7: 11-12.

8. Miles CA, Lumpkin TA, Zenz L (2000) Edamame. Washington State University Cooperative Extension Bulletin No PNW0525.

9. Rao MSS, Bhagsari AS, Mohamed Al (2002) Fresh green seed yield and seed nutritional traits of vegetable soybean genotypes. Crop Science.

10. Mebrahtu T, Mohamed A, Mersie W (1991) Green pod yield and architectura traits of selected vegetable soybean genotypes. J Prod Agri 4. 
Citation: Xụ Y, Sismour E, Pao S, Rutto L, Grizzard C, et al. (2012) Textural and Microbiological Qualities of Vegetable Soybean (Edamame) Affected by Blanching and Storage Conditions. J Food Process Technol 3:165. doi:10.4172/2157-7110.1000165

11. Mohamed Al, Mebrahtu T, Rangappa M (1991) Nutrient composition and antinutritional factors in selected vegetable soybean (Glycine max [L.] Merr.). Plant Foods Hum Nutr 41: 89-100.

12. Mebrahtu T, Mohamed Al, Elmi A (1997) Accumulation of phytate in vegetabletypes soybean genotypes harvested at four developmental stages. Plant Foods Hum Nutr 50: 179-187

13. Mebrahtu T, Mersie W (1999) Genetic variability for ozone insensitivity in vegetable-type soybean. Journal of New Seeds 1: 11-23.

14. Young G, Mebrahtu T, Johnson J (2000) Acceptability of green soybeans as a vegetable entity. Plant Foods Hum Nutr 55: 323-333.

15. Mebrahtu T, Devine T, Donald P, Abney T (2005) Registration of 'Asmara' vegetable soybean. Crop Science 45: 408-409.

16. Mebrahtu T, Devine T, Donald PA, Abney T (2005) Registration of 'Randolph' vegetable soybean. Crop Science 45: 2644-2645.

17. Mebrahtu T, Devine TE, Donald P, Abney TS (2007) Registration of Owens vegetable soybean cultivar. Journal of Plant Registration 1: 95-96.

18. Sugimoto M, Goto H, Otomo K, Ito M, Onuma H, et al. (2010) Metabolomic profiles and sensory attributes of edamame under various storage duration and temperature conditions. J Agri Food Chem 58: 8418-8425.

19. Prochaska LJ, Nguyen XT, Donat N, Piekutowski WV (2000) Effects of food processing on the thermodynamic and nutritive value of foods: literature and database survey. Med Hypotheses 54: 254-262.

20. Bahceci KS, Serpen A, Gokmen V, Acar J (2005) Study of lipoxygenase and peroxidase as indicator enzymes in green beans: change of enzyme activity, ascorbic acid and chlorophylls during frozen storage. J Food Eng 66: 187-192.

21. Barrett DM, Theerakulkait C (1995) Quality indicators in blanched, frozen, stored vegetables. Food Technology. 49: 62-65.

22. Lin Z, Schyvens $E$ (1995) Influence of blanching treatments on the texture and color of some processed vegetables and fruits. J Food Process Preserv 19 451-465.

23. Hemeda HM, Klein BP (1991) Inactivation and regeneration of peroxidase activity in vegetable extracts treated with antioxidants. J Food Sci 56: 68-71.

24. Dominguez R, Quintero-Ramos A, Bourne M, Barnard J, Talamás-Abbud R, et al. (2001) Texture of rehydrated dried bell peppers modified by low-temperature blanching and calcium addition. Int J Food Sci Technol 36: 523-527.

25. Pao S, Ettinger MR, Khalid MF, Mebrahtu T, Mullins C (2007) Microbiologica quality of frozen "edamame" (vegetable soybean). J Food Safety 28: 300-313.

26. Sheu SC, Chen AO (1991) Lipoxygenase as blanching index for frozen vegetable soybeans. J Food Sci 56: 448-451.

27. Zhang M, Li CL, Ding XL (2001) Effects of heating on thermal denaturation of several green vegetables suitable for dehydration. Int Agrophysics 15: 215-217.

28. Sessa DJ (1992) Hydration effects on the thermal stability of proteins in cracked soybeans and defatted soy flour. Lebensm-Wiss.U-Technol 25: 365-370.

29. Mozzoni LA, Chen P, Morawicki RO, Hettiarachchy NS, Brye KR, et al. (2009) Quality attributes of vegetable soybean as a function of boiling time and condition. Int J Food Sci Technol 44: 2089-2099.

30. Lee Y, Merritt CG, Dermody NE, Camillus (1989) Method of preserving color of vegetable pasta products. U.S. Patent No. 4, 840,808.

31. Seow CC, Lee SK (1997) Firmness and color retention in blanched green beans and green bell pepper. J Food Qual 20: 329-336.

32. Snyder HE, Kwon TW (1987) Soybean utilization. AVI Books, Van Nostrand Reinhold, New York.

33. Steinbuch $E$ (1976) Technical note: improvement of texture of frozen vegetables by stepwise blanching treatments. Int J Food Sci Technol 12: 435-436. 